\title{
THE EFFECTS OF DIFFERENT NITROGEN DOSES ON TUBER YIELD AND SOME AGRONOMICAL TRAITS OF EARLY POTATOES
}

\author{
Leyla GULLUOGLU ${ }^{1}$, H. Halis ARIOGLU², Halil BAKAL ${ }^{2}$ \\ ${ }^{1}$ Cukurova University, Vocational School of Ceyhan, Adana, TURKEY \\ ${ }^{2}$ Cukurova University, Faculty of Agriculture, Department of Field Crops, Adana, TURKEY \\ *Corresponding author: gulluoglu@cu.edu.tr
}

Received: 05.03.2015

\begin{abstract}
This study was conducted to determine the effects of different nitrogen rates on tuber yield and some agronomical traits of early potatoes grown in 2011 and 2012. The field trial was conducted at the experimental field of Cukurova University, in the Randomized Complete Block Designs, with three replications, with Marfona a medium early table potato. Zero, 40, 80, 120, 160, 200, 240, 280, 320 and $360 \mathrm{~kg} \mathrm{ha}^{-1}$ pure nitrogen doses were applied. According to the mean values of two years, the total tuber yield was 24.0 ton $\mathrm{ha}^{-1}$ in the control plot. The highest yield per hectare $\left(53.31\right.$ ton ha $\left.^{-1}\right)$ was obtained from the $240 \mathrm{~kg} \mathrm{ha}^{-1} \mathrm{~N}$ applied plots. Beyond $240 \mathrm{~kg} \mathrm{ha}^{-1}$ peak, as the dose was increased, the tuber yield was decreased. In addition, the marketable tuber yield ratio was $95.60 \%$ with $0 \mathrm{~N}$ dose. When the $\mathrm{N}$ dose increased to $200 \mathrm{~kg} \mathrm{ha}^{-1}$, the marketable tuber yield has also increased up to 97.41 . After $200 \mathrm{~kg} \mathrm{ha}^{-1}$ dose, the marketable tuber yield has started to decrease.
\end{abstract}

Keywords: Early potato production, Nitrogen fertilizer, Potato, Tuber yield

\section{INTRODUCTION}

Potato an annual tuber crop with high adaptation to various climatic zones, is successfully cultivated almost in every part of the world as nutritional source (Arioglu, 2014).

Potato, which contains valuable nutrients such as carbohydrates in the form of starch, proteins, vitamins and iron $(\mathrm{Fe})$ in its tubers, is consumed by humans directly as table potatoes and also as processed foods such as chips and French fries. In addition, its varieties that contain high levels of starch are utilized as raw materials in the production of flour, starch and alcohol, as well as animal feeding (Arioglu, 2014).

Due to its high nutritional value, potato could be considered one of the most important nutrients that could help to solve the starvation problem in the underdeveloped countries. Considering the starvation and malnutrition problems of millions of human beings, the Food and Agriculture Organization of the United Nations declared 2008 as the "International Year of the Potato" to promote awareness (Arioglu and Gulluoglu, 2014).

In the coastal regions of Turkey, where the Mediterranean type climate prevails with warm winters, potato is produced as early as possible with high tuber yield (Arioglu and Caliskan, 1999; Arioglu et al., 2002). The total potato production of Turkey in 2013 was 4.8 million tons; 300,000 tons of which were cultivated as the early potatoes (Anonymous, 2013).

The potato plant takes up substantial amounts of plant nutritional elements from the soil during the growing period. It stores approximately $1 / 2$ to $1 / 3$ of the plant nutritional elements in its vegetative parts. The remaining plant nutritional elements are stored in the tuber (Mikkelsen, 2006; Arioglu, 2014).

It was reported that when 3 tons of potato tubers are harvested per hectare, $150 \mathrm{~kg}$ of $\mathrm{N}, 60 \mathrm{~kg}$ of $\mathrm{P}_{2} \mathrm{O}_{5}, 350 \mathrm{~kg}$ of $\mathrm{K}_{2} \mathrm{O}, 90 \mathrm{~kg}$ of $\mathrm{CaO}$ and $30 \mathrm{~kg}$ of $\mathrm{MgO}$ per hectare are taken from the soil by the plants (Beukema and Van Der Zaag, 1979).

Potato plants require nitrogen fertilizers substantially. Studies conducted in the Erzurum province of Turkey by Karadogan (1996) and Ozturk et al. (2007) indicated that as the doses of nitrogen were increased, tuber yields were also increased. Since potatoes are produced in sandy soils and require substantial amounts of irrigation, the soil is subject to serious nitrogen leaching. Depending on the purpose of cultivation, it is vital that the nitrogen fertilizers should be applied to fields to compensate losses in the potato cultivation. Substantial amounts of nitrogen fertilizers applied at the early stages stimulate the development of vegetative parts with delay in tuber initiation ((Mikkelsen, 2006). So, this type effect of nitrogen fertilizers should be considered in the early potato production (Ozer ve Arıglu, 1994; Arioglu, 2014). 
In order to regulate tuber initiation and to prevent nitrogen leaching, the application of nitrogen fertilizers at two different times was suggested, such as the application of $1 / 2$ of the fertilizer at the time of planting, and half of the remaining $1 / 2$ at the time of the hilling (5 to 6 weeks after the plants emerge from the soil surface) and the rest when the tubers reach the size of an egg, increases tuber yield (Rosen and Bierman, 2008; Davis et al., 2014). The leaching of nitrogen should be considered in sandy soils so the amount of nitrogen fertilizers applied should be increased and the fertilizer should be applied by the sprinkler irrigation at several times (Yilmaz, 1992; Hochmuth and Hanlon, 2014).

The amount of nitrogen fertilizers to be used in potato cultivation should be based on the target crop quantity and the type of the soil, since potato plants require a certain amount of nitrogen intake from the soil for certain tuber yield levels. When aiming for certain levels of tuber yield from potato crop, the properties of the variety and the suitability of the environmental factors should also be considered (Rosen, 2013; Arioglu, 2014). The results of research conducted for main crop in the various regions suggested the application of 100 to $210 \mathrm{~kg} \mathrm{ha}^{-1}$ nitrogen fertilizers as the proper amount in order to reach high quality and quantity tuber yield per unite area in Turkey (Taskiran and Esendal, 1988; Kasap, 1994; Tuncturk et al., 2004). Previous research showed that the quantity of nitrogen fertilizers that should be applied in potato cultivation changes from region to region. But we do not yet have the results of early potatoes in the region. Therefore the purpose of this study was to investigate the optimal nitrogen fertilizer rate and its timing to obtain economic yield in the early potato production in the Cukurova region.

\section{MATERIALS AND METHODS}

\section{Research Materials}

The study was conducted at the Research Fields of the Cukurova University, Faculty of Agriculture (Southern Turkey, $36^{\circ} 59^{\mathrm{l}} \mathrm{N}, 35^{\mathrm{o}} 18^{1} \mathrm{E} ; 23$ elevation). The design of the field trial was the Randomized Complete Block with 3 replications, in 2011 and 2012 years. Marfona, a medium early potato variety, was used as a plant material. Potassium Sulfate $\left(50 \% \quad \mathrm{~K}_{2} \mathrm{O}\right)$, Triple Superphosphate $\left(42-44 \% \mathrm{P}_{2} \mathrm{O}_{5}\right)$, Ammonium Sulfate $(21 \%$
$\mathrm{N})$ and Ammonium Nitrate $(33 \% \mathrm{~N})$ were used as chemical fertilizers.

\section{Soil Properties of the Research Area}

The soil of the experimental field had a loamy structure with $\mathrm{pH}$ levels of 7.28-7.29. The salt content of the soil was $0.052 \%$ to $0.060 \%$. The usable $\mathrm{P}_{2} \mathrm{O}_{5}$ content was $14.17 \%$ at the upper layers with the content decreasing in the lower layers. In addition, the nitrogen content of the soil was $0.122 \%$ at the upper layers and $0.056 \%$ at the lower layers. The lime content was 33.02 $\%$ at the upper layers with the increased levels in lower layers.

\section{Climate of the Research Area}

In the Adana province of Turkey, winters are mild and rainy, whereas summers are dry and warm, which is a typical of a Mediterranean climate. The average monthly temperatures during the research period were 16.7 to 28.9 ${ }^{\circ} \mathrm{C}$ in 2011 , whereas it was in the 18.8 to $29.4{ }^{\circ} \mathrm{C}$ interval in 2012. The maximum temperature for Adana was 39.3 ${ }^{\circ} \mathrm{C}$ in 2011 and was $40.6{ }^{\circ} \mathrm{C}$ in 2012. The total precipitation was $184.7 \mathrm{~mm}$ and $110.4 \mathrm{~mm}$ in 2011 and 2012, respectively (Turkish State Meteorological Service Adana Regional Directorship, 2011 and 2012).

\section{Planting and Management}

The field was cultivated deeply by the moldboard following the harvest of the previous crop in the fall, and then the soil was prepared by using diskharrow. The plantings were done by hand in the second week of January in two years, with $70 \mathrm{~cm}$ between row distance and $30 \mathrm{~cm}$ in-row distance. The plot size was set as $14 \mathrm{~m}^{2}$ $\left(\begin{array}{lllll}2.8 & \mathrm{~m} & \mathrm{x} & 5.0 \mathrm{~m}\end{array}\right)$. Before planting, $550 \mathrm{~g}$ Triple Superphosphate $\left(42-44 \% \quad \mathrm{P}_{2} \mathrm{O}_{5}\right)$ and $450 \mathrm{~g}$ Potassium Sulfate $\left(50 \% \mathrm{~K}_{2} \mathrm{O}\right)$ fertilizers per plot were applied to the furrows by hand and afterwards seed tubers were placed in the furrows according to the given row spaces.

During the growing period, Ridomil was applied three times to prevent late blight (Phytophtora Infestans) and overhead sprinkler irrigation was applied two times. During the growing period, other standard cultural practices were applied at proper time intervals. The planned Nitrogen application doses and times are given in Table 1. 
Table 1. The Application of Nitrogen Doses and Times

\begin{tabular}{ccccc}
\hline $\begin{array}{c}\text { Treatment } \\
\text { Number }\end{array}$ & $\begin{array}{c}\text { Nitrogen Doses }(\mathbf{K g} \\
\text { ha }^{-\mathbf{1}} \text { ) }\end{array}$ & Planting & Nitrogen Application Time and Doses \\
\cline { 2 - 5 } & 0 & 0 & 0 & Tuber initiation* \\
2 & 40 & 40 & 0 & 0 \\
3 & 80 & 40 & 40 & 0 \\
4 & 120 & 60 & 60 & 0 \\
5 & 160 & 80 & 80 & 0 \\
6 & 200 & 100 & 100 & 0 \\
7 & 240 & 80 & 80 & 80 \\
8 & 280 & 100 & 100 & 80 \\
9 & 320 & 110 & 110 & 100 \\
10 & 360 & 120 & 120 & 120 \\
\hline
\end{tabular}

$* 5^{\text {th }}$ of April $2011 ; * * 25^{\text {th }}$ of April 2012

\section{Measurement of characteristics}

The tubers were harvested in the first week of June. The plants in the middle two rows of each plot were harvested by hand. The number of tubers plant ${ }^{-1}$, tuber yield plant ${ }^{-1}$, marketable tuber yield ratio (tubers in 25 $\mathrm{mm}$ ), dry matter content and tuber yield hectare ${ }^{-1}$ were determined following the harvest (Onaran and Arioglu, 1999). The standard analysis of variance was used to analyze the traits measurement. The Least Significant Differences (LSD) test was used to comparing the treatments at 0.05 level (Steel and Torrie, 1980).

\section{RESULTS AND DISCUSSIONS}

Tuber Yield and Marketable Tuber Yield

The total tuber yield per hectare and the percentage of marketable tuber yield values are presented in Table 2 .

Table 2. The Effect of Different Nitrogen Doses on Total Tuber Yield (ton ha ${ }^{-1}$ ) and the Percentage of Marketable Tuber Yield (\%) in the Early Potato Production at Adana-Turkey.

\begin{tabular}{|c|c|c|c|c|c|c|}
\hline \multirow{2}{*}{$\begin{array}{c}\text { N Dose } \\
\left(\mathrm{kg} \mathrm{ha}^{-1}\right)\end{array}$} & \multicolumn{2}{|c|}{2011} & \multicolumn{2}{|c|}{2012} & \multicolumn{2}{|c|}{ Mean } \\
\hline & $\begin{array}{c}\text { TTY* } \\
\left(\text { ton }^{*} \mathbf{h a}^{-1}\right)\end{array}$ & $\begin{array}{c}\text { PMTY** } \\
(\%)\end{array}$ & $\begin{array}{c}\text { TTY* } \\
\left(\text { ton }^{*} \mathbf{h a}^{-1}\right)\end{array}$ & $\begin{array}{c}\text { PMTY** } \\
(\%)\end{array}$ & $\begin{array}{c}\text { TTY* }^{*} \\
(\text { ton ha } \\
\text { (1) }\end{array}$ & $\begin{array}{l}\text { PMTY** } \\
(\%)\end{array}$ \\
\hline 0 & 20.76 & 95.6 & 27.53 & 95.6 & 24.06 & 95.6 \\
\hline 40 & 31.98 & 96.8 & 34.38 & 95.9 & 33.18 & 96.3 \\
\hline 80 & 36.68 & 97.1 & 48.66 & 96.0 & 42.67 & 96.6 \\
\hline 120 & 38.80 & 97.1 & 51.98 & 96.6 & 45.39 & 96.8 \\
\hline 160 & 41.24 & 97.5 & 54.81 & 97.0 & 48.03 & 97.2 \\
\hline 200 & 43.53 & 97.7 & 54.44 & 97.1 & 48.98 & 97.4 \\
\hline 240 & 45.93 & 97.6 & 60.68 & 96.4 & 53.31 & 97.0 \\
\hline 280 & 46.63 & 96.7 & 54.71 & 96.4 & 50.67 & 96.6 \\
\hline 320 & 44.50 & 96.4 & 53.14 & 96.4 & 48.82 & 96.4 \\
\hline 360 & 42.70 & 96.3 & 52.74 & 96.3 & 47.72 & 96.3 \\
\hline Average & 39.28 & - & 49.31 & - & 44.29 & - \\
\hline $\operatorname{LSD}(5 \%)$ & 6812 & 0.94 & 4162 & 0.68 & 12180 & 0.56 \\
\hline
\end{tabular}

* TTY: Total tuber yield; ** PMTY: The percentage of marketable tuber yield

Table 2 shows that the lowest tuber yields were observed when non nitrogen fertilizer was applied during the planting and the growing period, in both years. As the amount of nitrogen fertilizers applied was increased, tuber yield hectare ${ }^{-1}$ also increased substantially. The highest tuber yields hectare ${ }^{-1}$ were obtained from the plots where $280 \mathrm{~kg} \mathrm{ha}^{-1}$ (with 46.63 ton $^{-1}$ yield) nitrogen was

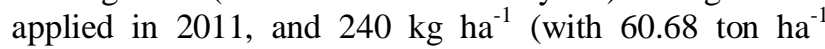
yield) nitrogen was applied in 2012. This increase has continued up to $280 \mathrm{~kg} \mathrm{ha}^{-1}$ nitrogen application in 2011 and $240 \mathrm{~kg} \mathrm{ha}^{-1}$ nitrogen application in 2012. Besides high nitrogen levels resulted in decreases in tuber yield. In addition, the tuber yield levels in 2012 were higher when compared to those in 2011. This could be due to the negatively affected vegetative growth of the plant as a result of low temperatures in 2011. Also, the seed tubers utilized in 2012 were comparatively bigger than those used in 2011. The highest tuber yield, based on the average values for both years, was observed in the plots where $240 \mathrm{~kg} \mathrm{ha}^{-1}$ of nitrogen fertilizer were applied, resulting in a total yield of 53.31 ton $\mathrm{ha}^{-1}$. Based on the average values for both years, it was observed that as the nitrogen fertilizers applied was increased, the tuber yield was also increased. This increase has continued up to $240 \mathrm{~kg} \mathrm{ha}^{-1}$ nitrogen application followed by a decrease in yield beyond that amount (Fig. 1). 


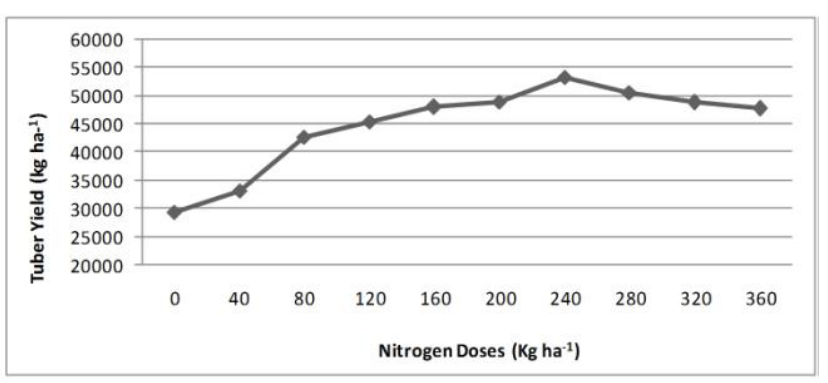

Figure 1. The Effect of Nitrogen Doses on Total Tuber Yield of Early Potato Growing at Adana-Turkey

This decrease could be explained as follows. The additional nitrogen stimulated the development of the vegetative growth of the plants. However, the vegetative parts of the plants did not utilize light energy sufficiently. But, the vegetative parts continued to respire, leading to a substantial amount of dry mater that resulted from photosynthesis to be consumed as a result of respiration. Consequently, the tuber yields were decreased. These findings are supported by Ozer ve Arıoglu (1994), Karadogan (1996) and Ozturk et al. (2007).

In potato growing, the marketable tuber yield is an important trait. The highest marketable tuber yield percentage $(97.4 \%)$ was obtained in the plots where 200 $\mathrm{kg} \mathrm{ha}^{-1}$ nitrogen fertilizer was applied. In 2011, this figure was $97.7 \%$, whereas in 2012, it was $97.1 \%$ (Table 2). Similar results were reported by other researchers (Taskiran and Esendal, 1988; Kasap, 1994; Tuncturk et al., 2004; Rosen and Bierman, 2008; Rosen, 2013).

\section{Tuber Number and Tuber yield per Plant}

The number of tubers and tuber yield of per plant are presented in Table 3.

Table 3. The Effect of Different Nitrogen Doses on the Number of Tubers and the Yield per Plant in the Early Potato Production at Adana-Turkey.

\begin{tabular}{|c|c|c|c|c|c|c|}
\hline \multirow{3}{*}{$\begin{array}{l}\text { N doses } \\
\left(\mathrm{Kg} \mathrm{ha}^{-1}\right)\end{array}$} & \multicolumn{4}{|c|}{ Year } & \multicolumn{2}{|c|}{ Mean } \\
\hline & \multicolumn{2}{|c|}{2011} & \multicolumn{2}{|c|}{2012} & & \\
\hline & TN* & TY** & TN* & TY** & TN* & TY** \\
\hline 0 & 4.7 & 358.3 & 7.3 & 590.7 & 6.0 & 474.5 \\
\hline 40 & 5.9 & 559.7 & 8.5 & 778.0 & 7.2 & 668.8 \\
\hline 80 & 6.6 & 642.0 & 10.0 & 1125.0 & 8.3 & 883.3 \\
\hline 120 & 6.8 & 679.3 & 10.7 & 1240.0 & 8.8 & 959,8 \\
\hline 160 & 7.1 & 722.0 & 10.8 & 1270.0 & 9.0 & 996.2 \\
\hline 200 & 7.4 & 761.7 & 10.8 & 1306.0 & 9.1 & 1034.0 \\
\hline 240 & 7.8 & 804.0 & 10.9 & 1329.0 & 9.4 & 1066.0 \\
\hline 280 & 7.6 & 816.0 & 11.2 & 1337.0 & 9.4 & 1077.0 \\
\hline 320 & 7.4 & 779.0 & 11.5 & 1396.0 & 9.4 & 1037.0 \\
\hline 360 & 7.0 & 747.3 & 11.5 & 1279.0 & 9.2 & 1013.0 \\
\hline Average & 6.83 & 686.9 & 10.32 & 1165.1 & 8.58 & 920.96 \\
\hline $\operatorname{LSD}(\% 5)$ & 1.15 & 119.0 & 1.98 & 189.8 & 1.11 & 108.1 \\
\hline
\end{tabular}

** TY: Tuber yield per plant $\left(\mathrm{g}\right.$ plant $\left.^{-1}\right)$

Table 3 shows that tuber number per plant in 2011 was in the range of 4.7 (control) to $7.8\left(240 \mathrm{~kg} \mathrm{ha}^{-1}\right)$ number plant $^{-1}$, and 7.3 (control) to $11.5\left(320 \mathrm{~kg} \mathrm{ha}^{-1}\right)$ number plant $^{-1}$ in 2012. The number of tubers per plant in 2011 increased up to $240 \mathrm{~kg} \mathrm{ha}^{-1}$ nitrogen fertilizer application, followed by decreases beyond that point. On the other hand, in 2012, as the amount of nitrogen fertilizer increased, tubers per plant increased as well. The reason for discrepancy between years could be the plants being affected by low temperatures in 2011 and the large seed tubers developed more main stem in 2012 (Arioglu, 2014). Based on the average of two years, the highest number of tubers per plant was obtained by $240 \mathrm{~kg} \mathrm{ha}^{-1}$ nitrogen fertilizer was applied (9.4 number plant $\left.{ }^{-1}\right)$. As the amount of nitrogen fertilizers applied increased, the number of tubers per plant also increased, as well (Ozer and Arioglu, 1994).

Means of plant yields in 2011 were 358.3 to $816.0 \mathrm{~g}$ plant $^{-1}$. In 2011, the highest yield was obtained in the plots, where $280 \mathrm{~kg} \mathrm{ha}^{-1}$ nitrogen fertilizer was applied. On the other hand, the tuber yield means for 2012 was ranged between 590.7 and $1396.0 \mathrm{~g}$ plant $^{-1}$, compared to the means in 2011. In 2012, the highest yield was obtained in the plot, where $320 \mathrm{~kg} \mathrm{ha}^{-1}$ nitrogen fertilizer was applied. The mean of 2012 were higher than those obtained in 2011. This difference could be due to low temperatures occurred in 2011. Beside large seed tubers might develop high vegetative growth, leading to increased yields. Based on the means of both years, the highest tuber yield per plant was obtained from $280 \mathrm{~kg}$ ha ${ }^{1}$ nitrogen fertilizer. The tuber yields in the control plots were $474.5 \mathrm{~g}_{\text {plant }}{ }^{-1}$, whereas it was $1077 \mathrm{~g} \mathrm{plant}^{-1}$ in plots, where $280 \mathrm{~kg} \mathrm{ha}^{-1}$ nitrogen fertilizer was applied. Beyond certain rates of nitrogen fertilizer applications, the tuber yield per plant started to decrease due to the excessive amounts of vegetative parts are not affecting photosynthesis positively in April and May in the Cukurova Region. These findings were in agreement with the findings of Ozer and Arioglu, (994), Karadogan (1996), and Ozturk et al. (2007).

\section{Dry Matter Content}

Dry matter content is presented in Table 4 . Table 4 shows that as amount of the nitrogen increased, the dry matter content in the tubers decreased in two years. The 
values for 2011 were between $15.63 \%\left(360 \mathrm{~kg} \mathrm{ha}^{-1}\right)$ and $18.63 \%\left(40 \mathrm{~kg} \mathrm{ha}^{-1}\right)$.

Table 4. The Effect of Different Nitrogen Doses on the Dry Matter Content (\%) of Tubers in the Early Potato Production at Adana-Turkey.

\begin{tabular}{cccc}
\hline \multirow{2}{*}{ N rate $\left(\mathbf{k g ~ h a}{ }^{-\mathbf{1}}\right)$} & \multicolumn{2}{c}{ Year } & \multirow{2}{*}{ Mean } \\
\cline { 2 - 3 } & $\mathbf{2 0 1 1}$ & $\mathbf{2 0 1 2}$ & \\
\hline 0 & 17.52 & 16.52 & 17.02 \\
40 & 18.63 & 17.77 & 18.20 \\
80 & 18.20 & 17.63 & 17.92 \\
120 & 17.90 & 17.38 & 17.64 \\
160 & 16.85 & 16.24 & 16.55 \\
200 & 16.80 & 16.15 & 16.48 \\
240 & 16.15 & 15.88 & 16.02 \\
280 & 15.90 & 15.23 & 15.57 \\
320 & 15.88 & 15.23 & 15.56 \\
360 & 15.63 & 15.27 & 15.45 \\
LSD $(5 \%)$ & 0.82 & 0.79 & 0.87 \\
\hline
\end{tabular}

The highest dry matter content (18.63\%) was observed from the treatment $40 \mathrm{~kg} \mathrm{ha}^{-1}$ nitrogen application at planting time. As the amount of nitrogen fertilizer increased up to $360 \mathrm{~kg} \mathrm{ha}^{-1}$, the dry matter content was decreased down to $15.63 \%$. Similar results were also obtained in 2012. The dry matter content decreased from $17.77 \%$ levels to $15.23 \%$ levels. When the results for both years are compared, it could be observed that the dry matter content was higher in 2011. The reason for this difference might be large tubers. As the tuber size gets larger, the dry matter content in the tubers starts to decreases.

The means for both years indicated that as the nitrogen rate increased, the dry matter content decreased. In the plots, where $360 \mathrm{~kg} \mathrm{ha}^{-1}$ nitrogen fertilizers were applied, the dry matter content in the tubers was $15.45 \%$, whereas it was $18.20 \%$ in the plots, where $40 \mathrm{~kg} \mathrm{ha}^{-1}$ nitrogen fertilizer was applied (table 3). As the amount of nitrogen fertilizers applied increased, the tubers get bigger and consequently, the dry matter content per tuber decreased, while water content increased. Therefore, in processing type potato cultivation, substantial amounts of nitrogen fertilizers should not be applied. These findings are supported by the findings of Mikkelsen (2006).

\section{CONCLUSIONS}

The results and their discussions show that the application type and amount of nitrogen fertilizers at different doses and periods resulted in substantial increases in yield. As the rates of nitrogen fertilizer applications increased, tuber yields were also increased, leading to some increases in net income. The optimal and most economical nitrogen fertilizer application level was $240 \mathrm{~kg} \mathrm{ha}^{-1}$, resulting in the highest net income and net income increase levels. Based on the results of the study, it could be suggested that $1 / 3$ of the fertilizer could be applied during the planting, $1 / 3$ applied during the tuber initiation, and the remaining $1 / 3$ during the period where the tubers reach the size of an egg.

\section{LITERATURE CITED}

Anonymous, 2013. İstatistik Bolumu İnternet Sitesi, Http://www.fao.org

Arioglu, H.H., M.E. Caliskan. 1999. Studies on the early potato growing possibilities in the Coastal Regions of Mediterranean. Second Potato Congress of Turkey, 28-30 June, Erzurum, pp.220-226. (in Turkish)

Arioglu, H.H., H. Incikli, B. Zaimoglu, L. Gulluoglu. 2002. Studies on the early potato growing in the Cukurova Region. Third National Potato Congress, 23-27 September 2002, Izmir, pp 117-123. (in Turkish)

Arioglu, H.H. 2014. Growing and Breeding of Starch and Sugar Crops. Text Book of Cukurova University, Publication number 188-A-57, Adana, Turkey. (in Turkish)

Arioglu, H., L. Gulluoglu. 2014. Potato production in Turkey and its problems. Agromedya, 2 (10) 76-82. (in Turkish)

Beukema, H.P., D.E. Van Der Zaag. 1979. Potato Improvment. IAC, s.224, The Netherlands

Davis, J. D., R.D. Davidson, S.Y.C. Essah. 2014. Fertilizing Potatoes. Colarado State University Extension, 5pp.

Hochmuth, G., Ed. Hanlon. 2014. A summary of N, P, and K Resarch With Potato in Florida. University of Florida UF/IFAS Extension, Gainesville,FL.,29pp

Karadogan, T. 1996. Application and rates of nitrogen and phosphorus on yield components and quality of potato. Journal of Ataturk University Faculty of Agriculture, 27 (1):50-60. (in Turkish)

Kasap, Y., 1994. The effects of different nitrogen levels and yield and dry matter contents in potato. $1^{\text {st }}$ Congress of Field Crops - Izmir, Volume 1: 260-262. (in Turkish)

Mikkelsen, R. 2006. Best Management Practices for Profitable Fertilization of Potatoes. Better Crops, 90(2):12-13

Onaran, H., H.H. Arioglu. 1999. Determination of suitable plant density for different tuber sizes in table potato growing in the Niğde province. $2^{\text {nd }}$ National Potato Congress, 28-30 June, Erzurum, Turkey, pp 284-297. (in Turkish)

Ozer, C., H.H. Arioglu. 1994. Determination of the effect of nitrogen fertilizer on tuber development and harvest date of early potato growing in the Cukurova Region. $1^{\text {st }}$ Congress of Field Crops, 25-29 April 1994 - Izmir, Volume 1, pp 185188.. (in Turkish)

Ozturk, E., K. Kara, T. Polat. 2007. The effects of form and application times of nitrogen on yield and tuber size of potato. Journal of Tekirdag Agriculture Faculty 4(2) 127135. (in Turkish)

Rosen,C.J., P.M. Bierman. 2008. Best Management Practices for Nitrogen Use: Irrigated Potatoes. University of Minnesota Extesion, 7pp

Rosen, C.J. 2013. Potato Fertilization on Irrigated Soils: Crops. University of Minnesota Extesion, 6pp.

Taskiran, A., E. Esendal. 1988. The effects of planting times and nitrogen doses on tuber yield and some characteristics of potato growing under farmer conditions. Journal of 19 Mayis University, Faculty of Agriculture, 3(2):25-45. (in Turkish)

Tuncturk, M., R. Tuncturk, B.Yildirim, T. Eryigit. 2004. The effect of different nitrogen doses and in-row spacings on yield and quality of potato. Journal of Yuzuncu Yil University, Faculty of Agriculture, 14(2):95-104. (in Turkish)

Yilmaz, A. 1992. A study on the effect of nitrogen applied at different times and doses on tuber yield, tuber size and some quality characteristics of potato growing in the Misli Plain. Doctoral dissertation Selcuk University, Faculty of Agriculture. (in Turkish) 